\title{
Kohesivitas Tim dan Sikap terhadap Kepemimpinan Wasit sebagai Prediktor Kecenderungan Perilaku Agresif Pemain Sepakbola
}

\author{
Amin Akbar ${ }^{1} \mathcal{E}$ Thomas Dicky Hastjarjo ${ }^{2}$ \\ Fakultas Psikologi, Universitas Gadjah Mada
}

\begin{abstract}
This study aims to determine the role of team cohesiveness and attitude toward referee leadership to the aggressiveness tendency in Indonesian professional football player. Participants in this research were 90 Indonesian professional football players in "Liga Satu Gojek-Traveloka". The data were collected using three instruments: aggressiveness behavioral tendencies scale, team cohesiveness scale, and attitude toward referee leadership scale. Data were analyzed using linear regression analysis in SPSS 20. Findings from this research were the team cohesiveness and the attitude towards referee leadership have contributed in aggressive behavioral tendencies of Indonesian professional football player, shown by the value of $R=0.509$ and $R$ square $=0.259 p$ $<0.01$. Team cohesiveness and the attitude toward referee leadership effectively contribute as much as $25.9 \%$ on the aggressiveness tendency among Indonesia professional football players.
\end{abstract}

Keywords: aggressive behavior; attitude toward referee leadership; team cohesiveness,

Abstrak. Penelitian ini bertujuan untuk mengetahui peran kohesivitas tim dan sikap terhadap kepemimpinan wasit pada kecenderungan perilaku agresif pemain sepakbola profesional Indonesia. Subjek dalam penelitian ini adalah pemain sepakbola profesional Indonesia yang berjumlah 90 orang dan tersebar di tujuh klub liga satu gojek traveloka Indonesia. Alat ukur yang digunakan dalam penelitian ini adalah skala kecenderungan perilaku agresif, kohesivitas tim dan sikap terhadap kepemimpinan wasit. Analisis data dilakukan dengan menggunakan analisis regresi linear berganda. Hasil penelitian ini menemukan bahwa kohesivitas tim dan sikap terhadap kepemimpinan wasit dapat berperan tehadap kecenderungan perilaku agresif pemain sepakbola Indonesia, dengan nilai $R=0,509$, serta $R$ square $R^{2}=0,259 p<0,01$. Kohesivitas tim dan sikap terhadap kepemimpinan wasit bersama-sama memberikan sumbangan efektif sebesar $25,9 \%$ pada kecenderungan perilaku agresif pemain sepakbola profesional Indonesia.

Kata kunci: kecenderungan perilaku agresif; kohesivitas tim; sikap terhadap kepemimpinan wasit

Hakuhodo (2012) melakukan penelitian tentang popularitas olahraga di 14 negara di Asia termasuk Indonesia untuk memberikan gambaran tentang olahraga yang paling digemari dan disenangi oleh masyarakat Asia. Hasil dari penelitiannya menyebutkan

\footnotetext{
${ }^{1}$ Korespondensi mengenai isi artikel ini dapat dilakukan melalui swinengkuh@gmail.com

2Atau melalui r.hidayat@ugm.ac.id
} 
bahwa 10 dari 14 negara mengatakan sepakbola sebagai olahraga yang paling populer untuk disaksikan. Indonesia menjadi salah satu dari 10 negara tersebut, dengan sepakbola sebagai olahraga paling populer untuk disaksikan dan menempatkan badminton di posisi kedua. Hal tersebut berbanding lurus dengan fenomena yang dapat kita lihat, salah satunya dengan penuhnya stadion ketika tim kebanggaan masing-masing individu bermain atau ketika Timnas bermain.

Sepakbola mendapatkan posisi khusus di hati masyarakat Indonesia baik sebagai olahraga maupun hiburan. Satu kritik yang harus diberikan terhadap sepakbola dunia dan khusus untuk sepakbola Indonesia yaitu tentang kekerasan yang terjadi di atas lapangan atau yang sering dikenal dengan perilaku agresif dalam istilah psikologi. Grange dan Kerr (2010) berpendapat bahwa perilaku agresif dalam olahraga cenderung mencerminkan definisi agresif pada umumnya yaitu suatu tindakan yang dilakukan dengan cara sengaja baik lisan maupun fisik yang dapat melukai orang lain, dan dilakukan dengan harapan bahwa perilaku ini akan berhasil. Perilaku agresif yang dilakukan oleh atlet adalah salah satu masalah yang serius pada olahraga modern.

Donahue, Rip, dan Vallerand (2009) dalam penelitiannya yang berjudul "When winning is everything" menemukan bahwa pemain dengan passion yang kuat terhadap suatu olahraga cenderung memiliki tingkat agresivitas yang lebih tinggi ketika mendapatkan sebuah ancaman dalam bentuk kekalahan atau tertinggalnnya skor dalam pertandingan dibandingkan dengan pemain yang passion nya dalam taraf yang biasa saja. Kemenangan merupakan target yang harus diraih sebuah tim untuk tetap menjaga asa keluar sebagai juara sebuah kompetisi.
Pelatih, official, maupun pemain akan melakukan cara apapun untuk keluar sebagai pemenang termasuk melakukan perilaku agresif dalam olahraga. Penelitian Kimble, Russo, Bergman dan Galindo (2010) menyebutkan bahwa dari periode Januari 1980 sampai dengan Desember tahun 2009 terdapat sekitar 239 penelitian tentang perilaku agresif pada berbagai cabang olahraga. Dengan kata lain perilaku agresif bukanlah suatu hal baru dalam dunia olahraga, apalagi perilaku tersebut cenderung terjadi pada olahraga jenis kontak dan sepakbola termasuk di dalamnya.

Penelitian Utomo (2012) secara kualitatif pada tiga orang pemain sepakbola di liga antar mahasiswa menemukan bahwa perilaku agresif dalam olahraga juga terjadi di Indonesia khususnya sepakbola. Hasil penelitian menyebutkan bahwa ada beberapa faktor yang menyebabkan munculnya perilaku agresif antara lain balas dendam, wasit yang tidak adil, lokasi pertandingan, hasil yang tidak sesuai, dan lain-lain. Secara bersama-sama ketiga subjek penelitian menyebutkan bahwa balas dendam merupakan faktor yang menyebabkan mereka melakukan perilaku agresif terhadap lawannya. Balas dendam dimaksudkan bahwa adanya tanggung jawab bagi seorang pemain untuk menyerang pemain lain ketika mendapatkan perlakuan kasar yang ditujukan untuk dirinya maupun untuk rekan satu timnya. Terbentuknya rasa keterikatan, kesatuan dan kekeluargaan antara pemain di suatu tim membuat para pemain merasa perlu untuk membalas perbuatan lawan. Munculnya penalaran bahwa jika salah satu keluarga diserang maka anggota keluarga lain bertanggung jawab untuk membalaskan perbuatan tersebut. Melanjutkan dari pernyataan balas dendam di atas, pernyataan terse- 
but biasa disebut sebagai kohesivitas dalam istilah psikologi.

Kohesivitas tim biasanya berdampak pada sesuatu hal yang positif seperti penelitian yang dilakukan oleh Carron, Bray dan Eys (2002) bahwa kohesivitas berdampak positif pada efektivitas kerja tim. Kohesivitas juga bisa menjadi dua mata pisau yang berbahaya artinya tidak hanya berdampak positif tetapi juga ada sisi negatif dari kohesivitas. Seperti kohesivitas untuk melakukan pembolosan atau apabila tim terlalu kohesif maka akan berdampak pada deindividuasi sehingga hal ini menjadikan pengambilan keputusan secara groupthink (Johnson \& Johnson, 2000). Safitri dan Adrianto (2015) melakukan penelitian tentang intensi perilaku agresif dan menjadikan kohesivitas sebagai prediktor yang dapat memprediksi munculnya perilaku agresif. Hasil penelitian menunjukan bahwa secara signifikan bahwa kohesivitas dapat memprediksi intensi perilaku agresif. Pescosolido dan Saavedra (2012) menambahkan bahwa kohesivitas yang tinggi dapat memperkuat munculnya perilaku yang fungsional dan disfungsional.

Selain itu peneliti juga melakukan wawancara pada tanggal 14 oktober 2016 dengan salah satu pemain PSIM (Persatuan Sepakbola Indonesia Mataram) Jogjakarta yang bermain di kasta kedua sepakbola Indonesia. Subjek menyatakan bahwa ketika rekan satu timnya mendapatkan perlakuan kasar dari lawannya apalagi jika kejadian tersebut berada di depan ataupun dekat dengan dia maka dia akan melakukan hal yang sama dengan apa yang dilakukan lawan terhadap temannya. Selanjutnya, ia menyebutkan bahwa faktor lain yang menyebabkan bermain menjurus kasar yaitu faktor kepemimpinan wasit, ketika wasit tidak dapat memberikan perlakuan yang adil dan wasit terkadang tidak mengambil keputusan pada tempatnya maka pemain akan melakukan semacam tindakan yang kasar. Buruknya kepemimpinan wasit dalam sebuah pertandingan memang menjadi sorotan pada sepakbola Indonesia.

Penelitian dari Fruchart dan Carton (2012) menjelaskan bahwa seorang wasit dapat mengacaukan jalannya sebuah pertandingan sepakbola. Kesalahan dalam pengambilan keputusan dapat memengaruhi sikap atau perilaku pemain sepakbola dan menjadi salah satu yang memicu terjadinya perilaku agresif dalam sepakbola. Sejalan dengan pernyataan di atas hasil penelitian dari Utomo (2012) juga menyebutkan bahwa dua dari tiga subjek penelitiannya menyebutkan bahwa kepemimpinan wasit merupakan faktor yang memengaruhi seorang pemain melakukan perilaku agresif. Wasit merupakan perangkat pertandingan yang bertugas untuk memimpin jalanya sebuah pertandingan.

Berdasarkan pernyataan di atas peneliti mencoba untuk menarik sebuah benang merah bahwa ada kecenderungan sebagian besar pemain menganggap bahwa wasit melakukan kelalaian dan mengambil keputusan yang tidak seharusnya. Terlepas dari kepemimpinan wasit yang menjadi sorotan pada sepakbola Indonesia, peneliti mencoba melihat dan mengkaji dari perspektif psikologi. Wasit adalah manusia yang juga bisa melakukan kesalahan dan melakukan keteledoran. Namun, apapun itu kesalahan yang dilakukan oleh wasit, sesuatu yang harusnya kita tanamkan pada pemain adalah bagaimana sikap pemain terhadap wasit yang akan berpengaruh terhadap perilaku pemain di lapangan.

Sikap merupakan evaluasi dari aspek dunia sosial, serta bagaimana evaluasi tersebut memunculkan rasa suka atau tidak 
suka, setuju atau tidak setuju terhadap objek sikap. Objek sikap dapat berupa ide, isu, orang, kelompok sosial (Baron \& Byrne 2003). Salah satu sumber yang membentuk sikap kita adalah melalui proses pembelajaran sosial (social learning) pelajaran yang kita dapat ketika kita berinteraksi dengan orang lain atau hanya sekedar mengobservasi suatu tingkah laku. Dalam penelitian ini pemain sepakbola merasakan dan mengamati bagaimana kepemimpinan wasit di dalam lapangan, sehingga pengalaman yang ada akan membentuk sikap pemain sepakbola dan dapat mempengaruhi perilaku pemain tersebut. Sikap yang terbentuk dari pemain bisa beranekaragam, bisa positif dan juga negatif, namun seringkali sikap negatif yang terbentuk dikarenakan pengalaman dan pengamatan terhadap kepemimpinan wasit.

Berdasarkan daftar bacaan berita yang peneliti telaah, semua tim mengeluh akan buruknya kepemimpinan wasit di Indonesia. Sehingga tidak heran kalau kita melihat bagaimana pemain meninggalkan lapangan karena keputusan dan kepemimpinan wasit yang mengecewakan. Pernyataan yang muncul pun bervariasi dari pelatih, pemain atau suporter serta munculnya meme, yel-yel dan nyanyian yang berlirik wasit goblog dan pernyataan kasar lainnya. Berkaitan dengan buruknya sepakbola Indonesia pada saat ini dengan segala bentuk perilaku agresif yang dilakukan oleh para pemain. Peneliti tertarik untuk melakukan pengujian mengenai kohesivitas dan sikap terhadap kepemimpinan wasit pada kecenderungan perilaku agresif pemain sepakbola Indonesia.

\section{Metode}

Subjek Penelitian

Subjek dalam penelitian ini berjumlah 90 pemain sepakbola profesional Indonesia dan sedang bermain di kasta tertinggi persepakbolaan Indonesia yaitu liga 1 Gojek Traveloka. Subjek penelitian diambil dari 7 klub profesional Indonesia yaitu Bhayangkara FC, Madura United, Sriwijaya FC, Persiba Balikpapan, Arema Malang, Persela Lamongan dan PS TNI.

\section{Cara pengumpulan data}

Adapun metode pengumpulan data pada penelitian ini adalah dengan menggunakan skala. Skala yang akan digunakan adalah skala model Likert yang menggunakan skala empat pada dua variabel bebas (kohesivitas tim dan sikap terhadap kepemimpinan wasit) dan menggunakan skala semantic differential pada variabel tergantungnya (kecenderungan perilaku agresif). Pada penelitian ini untuk memunculkan variabel tergantung yakni kecenderungan perilaku agresif maka disajikan terlebih dahulu sebuah skenario.

\section{Analisis data}

Model analisis yang digunakan dalam penelitan ini adalah teknik analisis regresi berganda. Analisis ini digunakan untuk memprediksi seberapa besar pengaruh (sumbangan efektif) variabel prediktor (bebas) terhadap variabel kriterium (Winarsunu, 2012). Penelitian ini merupakan penelitian kuantitatif sehingga diolah dengan menggunakan pendekatan statistik. Metode statistik yang digunakan pada penelitian ini yaitu teknik Multiple Linear Regression Analysis (MLR). Winarsunu (2012), menyebutkan bahwa analisis regresi ganda atau dua prediktor adalah suatu teknik statistik yang digunakan untuk menguji dua buah prediktor $(\mathrm{X} 1$ dan $\mathrm{X} 2)$ dengan variabel kriterium $(\mathrm{Y})$. 


\section{Hasil}

\section{Uji hipotesis}

Uji hipotesis dilakukan dengan metode analisis regresi linear berganda dengan metode enter. Hasil dari analisis regresi diperoleh nilai $F=15,189, p<0,001$ dan nilai $R=0,509$, serta $\mathrm{R}$ square $R^{2}=0,259$. Korelasi $R$ $=0,509$ dan nilai $F=15,189, p<0,01$ dengan nilai signifikansi (p) sebesar 0,001 menunjukkan bahwa kohesivitas tim dan sikap terhadap kepemimpinan wasit secara bersama-sama berkorelasi secara signifikan dengan kecenderungan perilaku agresif pemain sepakbola Indonesia. Dapat dikatakan juga bahwa kohesivitas tim dan sikap terhadap kepemimpinan wasit secara bersama-sama berperan signifikan terhadap kecenderungan perilaku agresif pemain sepakbola Indonesia. Nilai $\mathrm{R}$ square sebesar $\left(R^{2}=0,259\right)$ menunjukkan bahwa variabel kohesivitas tim dan sikap terhadap kepemimpinan wasit bersama-sama memberikan sumbangan efektif terhadap kecenderungan perilaku agresif pemain sepakbola Indonesia sebesar 25,9\%, sementara sisanya yaitu $74,1 \%$ dipengaruhi oleh faktor atau variabel lain yang tidak teridentifikasi dalam penelitian ini. Untuk lebih jelasnya dapat dilihat pada Tabel 1.

Jadi, berdasarkan hasil analisis regresi berganda diketahui bahwa kohesivitas tim dan sikap terhadap kepemimpinan wasit bersama-sama secara signifikan berperan terhadap kecenderungan perilaku agresif pemain sepakbola Indonesia. Hal ini sesuai dengan hipotesis penelitian ini bahwa kohesivitas tim dan sikap terhadap kepemimpinan wasit bersama-sama berperan terhadap kecenderungan perilaku agresif pemain sepakbola Indonesia sehingga hipotesis dalam penelitian ini diterima.

\section{Diskusi}

Penelitian ini bertujuan untuk mengetahui apakah kohesivitas tim dan sikap terhadap kepemimpinan wasit dapat memprediksi kecenderungan perilaku agresif pada pemain sepakbola Indonesia. Pertanyaan ini terjawab melalui analisis data yang peneliti lakukan serta ditemukan bahwa kohesivitas tim dan sikap terhadap kepemimpinan wasit bersama-sama dapat memprediksi kecenderungan perilaku agresif pemain sepakbola profesional Indonesia. Hal tersebut diketahui melalui nilai $F=15,189 \quad(p<0,01)$ sehingga hipotesis dalam penelitian ini terbukti dan dapat diterima.

Penelitian ini juga menghasilkan sumbangan efektif kedua variabel prediktor terhadap variabel dependen yang ditunjukkan dengan nilai $\mathrm{R}$ square sebesar 0,259. Hal ini berarti bahwa kohesivitas tim dan sikap

Tabel 1. Hasil Analisis Regresi Linear Berganda

\begin{tabular}{llllll}
\hline \multicolumn{1}{c}{$\begin{array}{c}\text { Variabel } \\
\text { dependen }\end{array}$} & \multicolumn{1}{c}{ Variabel independen } & $\mathbf{R}$ & $\mathbf{R}$ square \\
$\left(\mathbf{R}^{2} \mathbf{)}\right.$ & $\mathbf{F}$ & Sig \\
\hline Kecenderungan & Kohesivitas dan Sikap & 0,509 & 0,259 & 15,189, & 0,001 \\
Perilaku & Terhadap Kepemimpinan & & & & \\
Agresif & Wasit & & & & \\
\hline
\end{tabular}


terhadap kepemimpinan wasit bersamasama berperan terhadap kecenderungan perilaku agresif pemain sepakbola profesional Indonesia sebesar 25,9\%, sementara selebihnya sebesar $74,1 \%$ dipengaruhi oleh variabel lain yang tidak terindentifikasi dalam penelitian ini. Sejauh daftar bacaan dan pencarian peneliti belum ditemukan sebuah penelitian yang bersama-sama meneliti tentang kohesivitas tim dan sikap terhadap kepemimpinan wasit pada kecenderungan perilaku agresif pemain sepakbola.

Variabel dalam penelitian ini yaitu kohesivitas tim dan sikap terhadap kepemimpinan wasit dapat memprediksi kecenderungan perilaku agresif pemain sepakbola profesional Indonesia. Namun, dari kedua variabel prediktor tersebut hanya variabel sikap terhadap kepemimpinan wasit yang dapat menjadi prediktor terhadap kecenderungan perilaku agresif pemain sepakbola profesional Indonesia. Hal ini ditunjukkan melalui nilai beta $\beta=-0,503$ dengan nilai signifikansi yaitu $0,001(p<0,5)$, sementara pada variabel kohesivitas tim secara terpisah tidak dapat menjadi prediktor terhadap kecenderungan perilaku agresif pemain sepakbola profesional Indonesia. Hal tersebut ditunjukkan melalui nilai beta $\beta=$ 0,018 dengan nilai signifikansi $0,858(\mathrm{p}>0,05)$.

Penelitian ini menemukan bahwa sikap terhadap kepemimpinan wasit dapat memprediksi kecenderungan perilaku agresif pemain sepakbola profesional Indonesia. Hal ini sejalan dengan pernyataan Faturochman (2009) yang mengungkapkan bahwa sikap akan konsisten terhadap perilaku ketika terjadi pada beberapa kondisi. Berhubungan dengan hal di atas, Fazio (dalam Baron \& Byrne, 2003) menyebutkan bahwa dalam kondisi tertentu, sikap dan perilaku bisa terhubung secara langsung, teori ini memberikan contoh ketika ada seseorang yang masuk memotong antrian maka sikap akan memberikan respon yang otomatis terhadap perilaku. Hal tersebut juga dapat menjelaskan keterhubungan sikap dan perilaku dalam lapangan sepakbola, karena saat melakukan pertandingan kita tidak memiliki kesempatan atau waktu yang cukup untuk merefleksikan berbagai tingkah laku kita dengan hati-hati.

Pada penelitan ini perilaku yang diukur adalah kecenderungan perilaku agresif pemain sepakbola profesional Indonesia. Hasil dalam penelitian ini menunjukkan bahwa sikap terhadap kepemimpinan wasit berkorelasi negatif terhadap kecenderungan perilaku agresif pemain sepakbola profesional Indonesia, dengan nilai korelasi yaitu $-0,508(p<0,01)$. Sehingga dalam penelitian ini dapat dikatakan jika sikap pemain sepakbola rendah atau negatif terhadap kepemimpinan wasit maka pemain tersebut akan cenderung melakukan perilaku agresif, sebaliknya jika sikap pemain sepakbola tinggi atau positif tehadap wasit maka pemain cenderung tidak akan berperilaku agresif, baik terhadap wasit ataupun terhadap pemain lainnya sebagai target dari perilaku agresif. Hasil penelitian ini sesuai dengan penelitian dari Faiqoh dan Falah (2009) yang menyatakan terdapat hubungan negatif yang signifikan antara sikap dengan kecenderungan perilaku agresif dengan nilai korelasinya $-0,508(\mathrm{p}<0,01)$.

Penelitian ini juga menemukan bahwa kohesivitas tim tidak dapat menjadi prediktor yang signifikan terhadap kecederungan perilaku agresif pemain sepakbola Indonesia. Hasil penelitian ini sejalan dengan penelitian yang dilakukan oleh Drew and Braun (2005) yang menyatakan bahwa tidak terdapat hubungan antara kohesivitas dengan perilaku agresif atlet. Drew and Braun (2005) melakukan penelitian pada 174 
atlet di Midwest, penelitian ini mencoba melihat peran kohesivitas tim pada kecenderungan perilaku negatif atlet seperti mengkonsumsi minuman keras, melakukan kecurangan, berperilaku agresif. Hasil penelitian menunjukkan bahwa tidak terdapat hubungan antara kohesivitas dengan variabel yang disebutkan di atas. Sehingga hasil penelitian kohesivitas tim dengan kecenderungan perilaku agresif pemain sepakbola Indonesia sejalan dengan penelitian di atas. Kohesivitas tim sering dihubungkan dengan sesuatu hal yang positif seperti pencapaian sebuah tim dan kesuksesan sebuah tim.

Kohesivitas dapat digambarkan sebagai kesatuan kelompok, perasaan tertarik dengan anggota kelompok, dan sejauh mana anggota memusatkan upaya mereka untuk mencapai tujuan kelompok (Sabin \& Marcel 2014). Dalam bidang kelompok dan organisasi, tim olahraga merupakan suatu bagian yang unik dibandingkan dengan kebanyakan tim atau organisasi lain. Tim olahraga memiliki konsistensi dalam hal kemampuan anggota, tujuan, peran, hubungan, struktur tim, aturan yang lebih jelas dibandingkan dengan organisasi atau jenis tim lainnya (Wolfe et al. 2005). Berdasarkan penjabaran di atas maka dapat kita katakan bahwa setiap tim yang tergabung dalam pergelaran liga 1 Indonesia pasti memiliki satu tujuan yang jelas sebelum ikut dalam pergelaran liga. Tujuan yang dimiliki setiap tim adalah menjadi juara di pergelaran liga tersebut. Memenangkan setiap pertandingan adalah jalan yang harus ditempuh untuk keluar sebagai juara di liga dan memenuhi tujuan bersama.

Demi mencapai tujuan bersama diperlukan kohesivitas tim untuk menunjang performa pemain di dalam lapangan sebagai usaha untuk meraih kemenangan, artinya pemain harus menyalurkan kohesivitas tim pada hal yang positif dan semakin mendekatkan tim yang dibela mendapatkan gelar juara. Hasil penelitian oleh Anderson (2015) menyebutkan sebuah tim dengan adanya hubungan persahabatan lebih berhasil dalam hal kinerja sebagai sebuah tim dibandingkan tim yang pemain didalamnya hanya terhubung dan berelasi karena sebuah tugas. Senada dengan hal di atas Muthiane, Rintaugu dan Mwisukha (2015) juga menyebutkan bahwa tim dengan kohesivitas yang kuat cenderung memperoleh tingkat kemenangan yang lebih banyak daripada menderita kekalahan.

Sehingga dapat disimpulkan bahwa jika kohesivitas pemain tesebut diarahkan kepada sesuatu hal yang positif maka mereka akan semakin dekat dengan tujuan dari tim yaitu menjadi juara di akhir liga. Apabila kohesivitas tim tersebut bergerak ke arah yang negatif seperti melakukan perilaku agresif terhadap pemain lain, maka dapat menjauhkan tim tersebut dari tujuan bersama yaitu memenangi setiap pertandingan dan keluar sebagai juara di akhir liga. Dalam sebuah pertandingan apabila pemain terprovokasi untuk melakukan kecenderungan perilaku agresif atas dasar kohesivitas maka dapat merugikan tim tesebut, hal yang paling mungkin didapatkan dari perilaku agresif adalah hukuman kartu merah yang akan membuat tim kita kekurangan pemain untuk melanjutkan pertandingan. Hasil dari kekurangan pemain adalah kekalahan yang akan menjauhkan tim dari gelar juara.

\section{Kesimpulan}

Berdasarkan hasil penelitian dan pembahasan, maka kesimpulan yang dapat diberikan adalah kohesivitas tim dan sikap terhadap kepemimpinan secara wasit bersama-sama mampu memprediksi kecenderungan perila- 
$\mathrm{ku}$ agresif pemain sepakbola Indonesia. Kemudian sikap terhadap kepemimpinan wasit berkorelasi negatif dengan kecenderungan perilaku agresif dan dapat memprediksi kecenderungan perilaku agresif pemain sepakbola Indonesia. Hal ini menunjukkan semakin rendah sikap pemain terhadap kepemimpinan wasit maka akan semakin tinggi kecenderungan perilaku agresif pemain sepakbola Indonesia. Serta kohesivitas tim tidak dapat memprediksi kecenderungan perilaku agresif pemain sepakbola Indonesia.

\section{Saran}

Penelitian ini dapat dilanjutkan dengan mengkaji variabel-variabel lain seperti kecerdasan emosi, jenis kelamin, provokasi, pengaruh alkohol, suhu lapangan, bermain tandang atau kandang, perbedaan skor, posisi klasemen, atlet dan jenis olahraga serta karakter pelatih yang dapat berperan dalam memprediksi munculnya perilaku agresif pemain sepakbola profesional Indonesia.

\section{Daftar Pustaka}

Anderson, A. (2015). Relationships among team cohesion and performance, anxiety, retention, and satisfaction. A thesis presented to the faculty of the department of kinesiology. (Tesis: tidak diterbitkan). East Carolina University, United States America.

Baron, R. A., \& Byrne, D. (2003). Psikologi sosial (Terjemahan Ratna Juwita dkk). Jakarta: Erlangga.

Carron, A. V., Bray, R. S., \& Eys, M. A. (2002). Team cohesion and team success in sport. Journal of Sport Science, 20(2), 119126. doi: $10.1080 / 026404102317200828$

Coulomb, G., \& Pfister, R. (1998). Aggressive behaviors in soccer as a function of competition level and time A field study. Journal of Sport Behavior, 21(2), 222-231.

Donahue, E. G., Rip, B., \& Vallerand. (2009). When wining is everything: On passion, identity, aggression in sport. Psychology of Sport and Exercise, 10, 526534.

Drew, L., \& Braun, J. (2005). The effects of perceived team cohesion on alcohol consumption, aggression, and cheating. Hanover College.

Faiqoh, E., \& Falah, F (2009). Hubungan antara sikap terhadap pasien penyakit jiwa dengan perilaku agresif perawat pasien penyakit jiwa. Proyeksi, 6(1), 8999. doi: $10.30659 /$ p.6.1.89-99

Faturochman. (2009). Pengantar psikologi sosial. Yogyakarta: Pustaka

Fruchart, E., \& Carton, A. (2012). How do amateur soccer referees destabilize a Match?. Psicológica, 33, 435-449.

Grange, P., \& Kerr, J. H. (2010). Physical aggression in Australian football: A qualitative study of elite athletes. Psychology of Sport and Exercise, 11, 3643. doi: 10.1016/j.psychsport. 2009.04.006

Hakuhodo. (2012). Sports popular in 14 Asian countries. Jepang: Global HABIT.

Johnson, D. W., \& Johnson, F. P. (2000). Joining together group theory and group skills. New York: Practice Hill.

Kimble, N. B., Russo, S. A., Bergman, B. G., \& Galindo, V. H. (2010). Revealing an empirical understanding of aggression and violent behavior in athletics. Aggression and Violent Behavior, 15(6), 442-462. doi: 10.1016/j.avb.2010.08.001

Muthiane, C, M., Rintaugu, E, G., \& Mwisukha, A. (2015). The relationship between team cohesion and performance in basketball league in 
Kenya. International Journal of Applied Psychology, 5(4), 90-95. doi: 10.5923/j.ijap.20150504.02

Pescosolido, A. T., \& Saavedra, R. (2012). Cohesion and sports teams: A review. Small Group Research, 43(6), 744-758. doi: $10.1177 / 1046496412465020$

Sabin, S. I., \& Marcel, P. (2014). Group cohesion important factor in sport performance. European Scientific Journal, 10(26), 1-12. doi: 10.19044/esj.2014.v10n26p\%25p

Safitri, A., \& Adrianto, S. (2015). Hubungan antara kohesivitas dengan intensi perilaku agresi pada suporter sepak bola. Jurnal Psikologi Islami, 1(2), 11-23.
Utomo, G. C. (2012). Agresivitas pemain sepakbola: Studi fenomenologi tentang kekerasan pemain sepakbola tingkat universitas. (Tesis tidak dipublikasikan). Universitas Gadjah Mada, Yogyakarta.

Winarsunu, T. (2012). Statistik dalam penelitian psikologi dan pendidikan. Malang: UMM Press.

Wolfe, R. A., Weick, K. E., Usher, J. M., Terborg, J. R., Poppo, L., Murrell, A. J., \& Jourdan, J. S. (2005). Sport and organizational studies: Exploring synergy. Journal of Management Inquiry, 14(2), 182-210. doi: $\underline{10.1177 /}$ $\underline{1056492605275245}$ 